\title{
Digital Fabrication and Free Culture. One More Minor Becoming?
}

\author{
José Pérez de Lama Halcón \\ Universidad de Sevilla, Departamento de Historia, Teoría y Composición Arquitectónicas, Escuela Técnica \\ Superior de Arquitectura, Sevilla, España, perezdelama@us.es
}

\begin{abstract}
Resumen
Diferentes autores se refieren a la fabricación digital como la Tercera Revolución Digital, después de las revoluciones de la computación y la comunicación. Como ocurriera con las dos revoluciones precedentes, se generaron grandes expectativas en torno a las virtualidades políticas de estas nuevas tecnologías para dar lugar a relaciones de producción más libres e individuos más autónomos. Sin embargo, como también ocurriera con la computación y la comunicación, lo que realmente está ocurriendo demuestra que las supuestas virtualidades no llegarán a hacerse actuales sin una intensa implicación, organización y trabajo por parte de sectores activistas técnicos y sociales. Se discute el caso de la compra corporativa de la empresa pionera de hardware libre Makerbot, como ejemplo de la situación y punto de inflexión en las expectativas de los nuevos tecno-visionarios. Para concluir se propone una serie de posibles estrategias que podrían promover el desarrollo efectivo de un ecosistema libre y open source de fabricación digital.
\end{abstract}

Palabras clave: Makers, Revolución Digital, Máquinas Deseantes, Fab Lab

\begin{abstract}
Digital fabrication is meant to be a Third Digital Revolution, after those of computation and communication. As happened with the two preceding revolutions, great expectations have arisen around its political virtualities to promote freer and more horizontal production relations and more autonomous individuals. However, as happened before with computation and communication, actual events are showing that these alleged virtualities won't become actual without strong determination, organization and work by social and technical activists. The case of the corporate acquisition of open hardware pioneering company, Makerbot, is discussed as an example and turning point of the initial optimism among the new generation of tech-visionaries. A set of possible strategies to promote a free \& open source digital fabrication ecosystem is discussed as a conclusion.
\end{abstract}

Key words: Makers, Digital Revolution, Desiring Machines, Fab Lab 


\section{The Difference Engine.}

The Difference Engine. Written in 1990 by William Gibson and Bruce Sterling; after [almost] a quarter of a century, one of the cyberpunk classics. The foundational oeuvre of steam-punk, too. The plot is captivating, but rather predictable, - disappointingly pulling on the most basic readers' passions. The set-up, however, is fascinating. What made me think of The Difference Engine in relation to the state of the art (and maybe politics) of digital fabrication, is that, too often, when reading Gibson's and Sterling's piece, one (at least I do) wonders whether the role and characters of the "good" and "bad guys" are somehow swapped; _ or maybe not exactly swapped, but thoroughly mixed up, as in, let's say, a schizo-cocktail.

As many of the readers probably know, the novel develops in an alternative historical context, that, as usually happens in Gibson's work, constitutes the novel's main character and its really experimental component, - rather than the actual plots, which are usually enjoyable, but somehow trivial. In Gibson's work characters are also often memorable; _ not so much in The Difference Engine, however, - apart from some secondary ones such as Ada Byron-Lovelace. The fictional-historical context, let us remember it is as follows: The computer revolution has indeed happened in Victorian England, around the 1820's to 1830's. Lord Byron, the poet and writer, is the President of the state and Lord Babbage, the computer inventor - the actual inventor of the real Difference Engine, - reputed to be the first conceptualization of a mechanical computer - is the executive prime minister. The aforementioned lady Ada Byron-Lovelace ${ }^{1}$, daughter of Byron and close friends with Babbage, - called by the people the Queen or Enchantress of Numbers, a great mathematician, has however become a derelict character, surrounded by a posse of semi-criminal pals, - haunted by alcohol, drugs, and and obsession with discovering, or developing, the modus, a computer program to win in horse races and casino betting.

Great scientific, engineering and social advances have been made in England, pushing the country into unprecedented progress. The country is run by a rather benign elite party of scientists and computer engineers, the Industrial Radical Party, the so called Rads, that have violently overturned the old aristocratic preindustrial regime - a bourgeois revolution. It is understood that political decisions are supposed to be made according to scientific methods and criteria. A strong workers union has supported the Rads to create this new[old] world, and some of its most outstanding scientists-politicians, such as Isambard Kingdom Brunel and Babbage himself, are venerated with awe by the population. Somehow the postwar dream as enunciated by Buckminster Fuller ${ }^{2}$, and of all technocrats throughout the second part of the 20th Century, is imagined by Sterling and Gibson as having happened in the British Empire around the 1850s. A similar technical and social development is shown in the novel to be happening in France, whose huge mainframe, the Napoleon, is going through some trouble while the story's action unfolds. This were indeed in France the years of the Second Empire and Baron Haussmann, another technocratic, - at the time called Saint-Simonian -, political regime [Harvey, 2006]. However, in The Difference Engine, there still are some discontents. Let's remember, 1830 and 1848 and then 1871 in Europe where dates of revolutions and extraordinary social turmoil. Marx and Engels publishing indeed The Communist Manifesto, in 1848... In the novel there are discontents in Britain with the excessive power and wealth of the Rads while poverty and disenfranchisement still remain; - according to the discontents, this being the general condition among the majority of the people.

The authors, offer some hints, too, on the situation of their fictional world beyond Britain and France. Anecdotally, Manhattan has become a commune, under Karl Marx's leadership. The rest of todays United States, still the Wild West, where British scientific explorers and adventurers, such as Edward Leviathan Mallory, the main character of the story, are used by Empire for trafficking arms and deploying political intrigues. Leviathan is an eminent adventurer-paleontologist, some kind of Indiana Jones, whose name, related to his North-American discoveries, is nevertheless disquieting. He becomes indeed the arm of imperial-bourgeois-law-and-order against major lumpenproletariat riots sparked by The Stink, a catastrophic episode of pollution during a heavy London summer. The mysterious leader of the riots is a so called Captain Swing, a mythical name in English counter-cultural tradition often associated to the Luddite movement ${ }^{3}$.

${ }^{1}$ Byron, Babbage and Ada Lovelace are of course real historical characters whose story is cleverly and suggestively re-written by Sterling and Gibson in The Difference Engine. Ada Byron-Lovelace is attributed to be the inventor of the idea of software, and as such, an importante character in the cyber-feminist pantheon.

${ }^{2}$ On Buckminster Fuller's technocratic dreams see for example: Marc WIGLEY, 2000, Man Plus

3 See an introductory note on the popular legendary figure of Captain Swing in: http://en.wikipedia.org/wiki/Captain Swing [visited 08.09.2013] 
The riots are presented as a mix of Situationism in its expression and the Paris Commune in its composition and demands. However these references are not idealized in any way, but rather presented as absurd and even hideous, its leaders mixing the pursuit of political unrest, social chaos and debauchery in similar parts. The team of good-guys is made up by three brothers, - the adventurer-academician, an army officer, and a young engineer , plus a policeman! In the novel they behave with more courage, discipline and intelligence than the the rebels, gunning their way around -, defeating the revolutionaries with the final help of imperial men-o-war bombing the rioters' stronghold... Leviathan Mallory gets his services paid by becoming in his older days the head of one of the most powerful imperial scientific societies. Some corrupt politicians and scientist are cleansed from the governmental party. Law-and-order-and-science eventually prevail. Characters in marginal plots, - a beautiful woman daughter to the original Luddite leader, a kinotropist [new media] artist and inventor, a hacker-and-political wannabe -, disappear somehow nostalgically from the center of the scene, leaving no traces...

With this attempt of outline I have offered here, one cannot say that The Difference Engine, is a critical piece of literature. At least not in an obvious way. It resembles too much what has been happening with the contemporary non-fictional, if it maybe said so, successive digital revolutions that we have actually been experiencing in the last 50-60 years. Great expectations and poor achievements - at least from a social emancipatory perspective. And now, after the communications and computer revolutions, here comes the digital fabrication revolution [Gershenfeld, 2005; Rifkin, 2011; Anderson, 2012]. And we might, - and probably should -, ask ourselves, to which extent and in what sense the former have been revolutions indeed. What were the various expectations around them and what did actually happen. And eventually, what are the actual discourses and desires for this new digital fabrication revolution, - and what might we reasonably - and maybe unreasonably, too - expected.

\section{The believe in the revolutionary powers of science and industry.}

First of all, there has to be made a clear difference between technological revolutions and social and political ones. It is true, that new technological developments allow for new production and distribution, organizational and social control or even biopolitical systems. However, we will substitute here the use of the terms system or structure, by that of machines, in the sense used by Deleuze and Guattari; - which means that there are no intrinsic or essential connections or ties between the various heterogeneous elements composing them, but rather that they are put to work together by specific desiring-machines [Deleuze and Guattari, 1972]. This, of course, is an hypothesis. More on it further on.

We could place one of the origins of the believe in science and specifically industry as a way to improve society in the works of French thinker and social activist Claude Henri de Rouvroy, comte de Saint-Simon, around the beginning of the 19th century. Of course, the Enlightenment did strongly believe in knowledge, science and education to free Humanity; but with Saint-Simon this took a more pragmatic and applied turn [Harvey, 2006]. The appearance of mechanical devices, in England, as depicted for example by Friedrich Engels in his The Conditions of the Working Class in England in 1844 still witnesses the single-minded use of mechanical devices in the leading textile industry as a straight forward way to reduce capitalists dependence upon skilled and non-skilled labor and to increase surplus value. Simultaneously to the The Conditions, however, the so called Utopian Socialists, - Fourierists in France, and later on in the US; Owen in Great Britain... -, were already speculating and practically exploring the application of machines and the industrial model to experimental socialist designs. Marx (and Engels) incorporated in their Scientific Socialism this approach to the industrial system. Industrialization with its concentration of workers in large cities and factories, created the conditions, according to their view, for the emerging proletariat to take hold of the production processes, and through it of political control, in order to make a freer and more egalitarian society. In their view, at least in some moment of the development of their thinking, industry and machines were not the enemies anymore, - as had been for the early Luddites -, but the necessary condition for a radical, socialist revolution.

Even if this cannot be the place and time to discuss this very rough sketch of Marxist ideas, it might be mentioned that there was a certain determinism in it that history, that the multiple later embodiments of industrial civilization, from liberal and neoliberal ultra-capitalism to Keynesianism, to Soviet socialism to Scandinavian welfarism, to contemporary Chinese communist-capitalism -, has proved to be wrong. However, we may say that intense processes of technological change contribute to cause significant, even radical, productive, economic, social and cultural changes, and associated with them significant shifts in hegemony and power relations. In these power shifts, considering it in a Foucaultian sense of the term, - that is as the ability to influence others behaviors -, new forms of rent distribution can be achieved, various freedoms and forms of autonomy can be conquered, etc. However, it has been observed, especially during the 20th century, the extraordinary capacity of capitalism to adapt itself and mutate according to continuously changing conditions and to implement whatever changes might 
occur in their own benefit, capturing them into its hegemonic desiring machine. On the other hand, employees and non-capitalist workers as collectives have shown a much poorer competence taking advantage of the continuously changing environment, - but, maybe, trying to turn themselves into capitalists or capitalist allies. It is to be questioned whether a general discontent with the system prevails, - as some of us fancy.

\section{Digital revolutions; hopes and disappointments.}

In the 1960's and 70's, together with the epidemics of middle class discontent in the so called advanced societies that coalesced around the global 68 revolutions, the rise of the communications and the computer revolutions made a new wave of techno-hopes-for-a-better-world to emerge. 50 years later, after successive metamorphosis, this concatenation of waves is still happening today: personal computers, the Internet and the early WWW, the web2.0, mobile ubiquitous connectivity, the Internet of Things, and now... digital fabrication.

I was not an early adopter, but did loose my hair participating in the latter decades of this revolution, and now my beard is growing gray still trying to surf it; or rather swim diagonally through it. I got my first computer around 85, my first Mac in 88, made my first website in 97, participated in radical free software and free networking collectives through the turn of the century, made my first digitally fabricated object (or proto-spime ${ }^{4}$ ) and founded a fab lab in 2009... Initially I was an enthusiast; then I became a radical-critical enthusiast, and now I am just trying to struggle... Participating, sometimes in the first line was exciting. But all the promises and expectations have truly not been satisfied. These days, writing in a hotel room in Akiba, Tokyo, the consumer-electronics-andentertainment-software capital of Japan, - Sega, Nintendo, Sony... - I feel rather alienated... Even if I love the hacks made to Kinect...

Somewhere else, I wrote in more detail about the successive emancipatory machines conceptualized and to a certain extent developed around digital culture since the 1970's [Perez de Lama, 2011]. As far as I understand, they might indeed be some of the most relevant human inventions-constructions of the late 20th century: personal computers, with heroes such as Lee Felsenstein and Steve Wozniak [Levy, 2010]; the public domain licensed WWW, with Tim Berners-Lee as its main initiator [Berners Lee, 2000; Rheingold, 2002]; free software, with, first of all, Richard Stallman, and then so many others [Kelty, 2008]; much more recently, free hardware (Arduino and Reprap projects...); and maybe, now, the latest hit, fab labs, whose leadership we have to attribute to Neil Gershenfeld before any other [Gershenfeld, 2005, 2012]. All these techno-social ensembles, no doubt interconnected between them, share(d) the goal of, and believe(d) in, empowering people through easy and economic access to information processing machines, initially, and later on, to unprecedented possibilities of networking and sharing [Rheingold, 2002; Benkler, 2006; Hard, Negri, 2009].

Much has been written about the supposedly inherent democratizing character of Internet based technologies [Castells, 1997; Benkler, 2006], fundamentally related to its potential for non-centralized or distributed information production and exchange, and to some extent, to the economic accessibility to the means, - computers, smartphones, Internet connection -, to actively participate, and collectively build contents and meaningful experiences, and even business schemes, in the web. In the case of actual information and knowledge production, the Internet and the WWW, have indeed significantly distributed power among a much wider population that that of the industrial period characterized by the centralized production of newspaper, radio and $t v$, on one hand, and publishing industry, and formal universities and research centers, on the other. Recent developments in free hardware and digital fabrication may extend in some ways the ability to produce material objects in distributed grass-roots empowering organizations [Pettis, Kaziunas et ali 2012; Gibb, 2010; Banzi, 2009; Bowyer, 2007] . The questions of machine costs and actual materials and energy supply, however, constitute, right now, obvious limitations, compared to knowledge and information production which have a low cost - not including the actual work itself.

At the same time, capitalism, as already mentioned, has shown an extraordinary capacity and creativity tweaking the new tools and networks in its own interest, using them, one would say, to reproduce and amplify its overall power. Surely there are multiple new actors, - the great digital barons such as Gates and Jobs, Brynn, Page, Zuckerberg or Slim, as well as many others not as popular as these -. The feeling however, and probably the fact, is that the core values and social relations of capitalism haven't changed much. Even if wealth might be produced now in networks [Benkler, 2006], or in the commons, as others would say [Hardt and Negri, 2009; Barnes, 2006], accumulation still occurs in patterns, or at least with results, too similar to the immediately preceding ones,

\footnotetext{
${ }^{4}$ According to Bruce Sterling, spime is a new kind of object we are moving towards: designed in a screen, digitally fabricated, that can be digitally tracked throughout its life to be eventually be recycled; Sterling, 2005, Shaping Things.
} 
production of subjectivity is astonishingly more and more centrally controlled, and liberties and autonomy of individuals and small groups, but those in extremely powerful positions, is rather receding than advancing; and it is to be questioned whether, in this new conditions, human experience is becoming richer and more varied or rather not [Bifo, 2003, 2007; Holmes, 2007]. As pre-visualized by Foucault, Guattari and Deleuze [Deleuze, 1987 \& 1992; Guattari, 2000], among others such as William Burroughs, there has been a qualitative transformation in the forms of power, from early disciplinary technologies that characterized industrial times to society-of-control or biopower 2.0 technologies, developed or evoloved to control people in the new fields of open networks, rather than in the older spaces of enclosure, such as the factory, the school or the nuclear family home. And then again, while the aim of discipline was to make people productive, one wonders whether this would still be the aim of biopower 2.0, or rather, whether its aim is now to have a minority of consumer-producers connected to the global finance based economy, while the goal for the rest of us, just keeping us under control, while leaving us to carry out some kind of infra-life in the outer fringes of society and legality: precarious temporary workers, long term unemployed, working poor, illegal migrants, and so on. This is, with no hesitation, the feeling in countries like Spain, with a $50 \%$ unemployment rate among young people, where large companies however keep increasing their benefits. The paradox being that the majority of these disenfranchised population still keep admiring and looking up at those who continue exploiting them, cooing the same dreams of success, individualism, conspicuous leisure and consumption of those who would rather like us to disappear - as long as they still keep some, few in any case, to silently perform the dirty work necessary to keep their luxury lives going on.

\section{Desiring machines, and social and technical machines.}

Deleuze and Guattari wrote indeed about desiring-machines and their connection to social and technical machines as something we ought to pay attention to [2009, pp. 111-112]:

[...] desiring-machines are indeed the same as technical and social machines, but they are their unconscious, as it were: they manifest and mobilize the investments of desire that "correspond" to the conscious or preconscious investments of interest, the politics, and the technology of a specific social field. To correspond does not at all mean to resemble; what is at stake is another distribution, another "map", that no longer concerns the interests established in a society, nor the apportionment of the possible and the impossible, of freedoms and constraints, all that constitutes society's reasons. But beneath these reasons, there are the unwanted forms of a desire that invests the flows as such, and the breaks in these flows, a desire that continually reproduces the aleatory factors, the less probable figures, and the encounters between independent series that are at the base of this society, a desire that elicits a love "for its own sake", a love of capital for its own sake, a love of bureaucracy for its own sake, a love of repression for its own sake, all sort of strange things such as "What does a capitalist desire from the bottom of his heart?" and "How is it possible that men desire repression not only for others but for themselves?" and so on.

The quote is extracted from a 1972 text by the authors, Balance-sheet of Desiring-machines, that was appended to the second edition of Anti-Oedipus. The text seems to me to suggest that technical machines could be assembled with different desiring-machines in order to achieve different events of the real: "they are the same machines, but is not the same regime" [p: 107]. Deleuze and Guattari, go on writing [p: 110]:

[...] a desiring-machine: the ensemble composed of a full body that engineers, and men and tools engineered on it [...] For example, there is the full body of the steppe which engineers men-horse-bow, a full body of the Greek city-state which engineers men and weapons, a full body of the factory which engineers men and machines...

Could we think then of the full body of the collaborative digital networks that engineers men (and women) and free digital fabrication tools? What does this actually mean, if this were an appropriate question with these authors; while at the same time, we do have to make ourselves the question, if we want to pursue other modes of action. However, these might not indeed be the right form to formulate the question [p: 106]:

Our relationship with machines is not a relationship of invention or imitation: we are not the cerebral fathers nor the disciplined sons of the machine. It is a relationship of peopling: we populate the social technical machines with desiring-machine, and we have no alternative.

It might be then a question of peopling, maybe of inhabiting, of becoming. Eventually, and making the transition to digital fabrication a final quote from Deleuze and Guattari [107-108]:

[...] Ivan Illich shows the following: that heavy machines imply capitalist or despotic relations of production, involving dependence, the exploitation, and powerlessness of men reduced to the condition of 
consumers or servants. The collective ownership of the means of production does not alter anything in this state of affairs, and merely sustains a Stalinist despotic organization. Accordingly, Illich puts forward the alternative of everyone's right to make use of the means of production, in a "convivial society", which is to say, a desiring and non Oedipal society. This would mean the most extensive utilization of machines by the greatest possible number of people, the proliferation of small machines and the adaptation of the large machines to small units, the exclusive sale of machinic components which would have to be assembled by the user-producer themselves, and the destruction of the specialization of knowledge and of the professional monopoly [...] And its not even on behalf of relatively simple machines that the desiring "convivial revolution" has to be made, but on behalf of machinic innovation itself, which capitalist or communist societies do everything in their economic and political powers to repress.

Machinic innovation then. Not only technical innovation, but innovation, too, in the social, institutional, spatial, material, and desiring components that make up Deleuze's and Guattari's machines; and this might be more intriguing and challenging: machines that cannot be designed or imitated, but rather peopled... Cyborg, collective, becomings.

\section{Peopling the free hardware machine: the MakerBot-RepRap affair 2013}

I will use then this idea-concept of peopling machines to present some cases that I think are relevant to discuss the state of the art of digital fabrication. The first case is that of the various vicissitudes that happened around the RepRap-Makerbot community during 2012-2013.

Briefly introduced, the background and main events are as follows. In 2009 three young techies [Zach Smith aka Hoeken, Pre Pettis and Adam Mayer], connected to a hacker space in Brooklyn called NYCResistor, launched a small business, MakerBot Industries, to fabricate and sell user friendly 3D printers derived from Reprap [Hoeken, 2012; Pettis, 2011]. RepRap, initiated by Adrian Bowyer at the University of Bath, England, is a conceptual machine, 3D printer, that is conceived to be self-reproducing; that is, a Reprap can ideally make another RepRap. Additionally it's source code is intentionally free, as in free software, so that anyone can download it and make his/her own. The first functional RepRap was built by Bowyer and his team in 2006 [Giloz, 2013]. To illustrate the relations and differences between the two machine developments, we could compare them with the relations between Debian-Linux and Ubuntu. MakerBot, which used a strong community policy with wiki forums and open source documentation, including material supplies, and Thingiverse.org [2008] a website to share designs, was a slow but firm worldwide success, developing several improved models between their foundation and 2013: ThingO-Matic and Replicator (1), plus several versions for the electronics and software components. In august 2011, MakerBot negotiated a venture capital investment of ten million US dollars [Pettis, 2011b]. After the management changes derived from the $10 \mathrm{M}$ investment, in may 2012, Zach Hoeken decided to abandon, or rather was pushed out of, the executive part of the company [Chris Thompson, 2012]. In the summer of 2012 a Kickstarter project was published offering the production of a replica of Replicator 1, to be produced in China, at a rather significant lower retail price [Flaherty, 2012]. Shortly after, september 2012, MB announced that their next model Replicator 2 , a semiprofessional version of the preceding one, - a prosumer version -, would have part of its source code closed [Pettis, 2012]. Through this period MakerBot hired a lawyer to remodel intellectual property policy in Thingiverse [Thingiverse, 2012]. This upset some relevant contributors such as Josef Prusa, one of the main RepRap community contributors, - who, making it very public, decided to retire all of his designs from the site [Prusa, 2012]. The same day of the Replicator 2 close source announcement, and the following days, an impassioned debate sparked online, with Pre Pettis, Hoecken and Reprap initiator and MakerBot founderstakeholder Adrian Bowyer as main contributors. Eventually, in june 2013, the media announced the acquisition of MakerBot by Stratasys, a corporate 3D printer company, paying 400 million US dollars, with founder and CEO Pettis "remaining on board" [Lobosco, 2013]. The media release claimed sales of 11.000 machines by MakerBot in the preceding 9 months, and a total of 22.000 since 2009.

One of the most interesting moments in this process was that of the worldwide debate when MakerBot's Bre Pettis announced that it would be closing part of the code of its Replicator 2 upcoming model.

Pettis, who in the previous years had been extremely outspoken about sharing knowledge, justified their decision to "not share the way the physical machine is designed or our GUI" invoking The Unspoken Rules of Open Source Hardware [Torrone, 2012], probably affected by the Kickstarter clone announced some months before ["cloning is not cool"], the huge difficulties in scaling up the business, - that included 100 plus employees and sending assembled, and therefore functioning machines, instead of DIY kits as MB had been doing until then -, as well as, - as some commentators suggested -, the influence of the new venture capitalists supporting MakerBot. The community was clearly split between two poles, showing the already historical schism between free software and open source thinking and practices [Stallman, 2004; Perez de Lama, 2010]. 
There were several parallel debates, with hundreds of comments, many of them by well known members of the OSH [Open Source Hardware] community. Some vocal contributions defended the free software point of view; particularly critical were the arguments discussing the contributions of the community to the actual technical development and success of MakerBot, and whether it was fair - ethical - that MakerBot, having taken advantage of all this contributions, was then closing its code. For example:

[...] You know, If the RepRap folks had said that 6 years ago, Makerbot and more than a dozen other companies that used RepRap's core IP to make money (while building the future) wouldn't be in business. In fact, this whole sector of the economy, poised to grow so rapidly, would still be relegated to $\$ 50,000$ Z-Corp Machines [...] [H. Snow, September 24, 2012 at 1:39 pm; comment on: http://www.makerbot.com/blog/2012/09/24/lets-try-that-again/ ]

or this other one:

Bre, I think you are missing the point.

It is great that you provide a high quality $3 \mathrm{~d}$-printer that work out of the box to all those who do not want to 'break and hack' their machine, but that is not a reason to go closed source.

You built your machine based on RepRap technology and created a company around it and its community. MBI promised to be an open source hardware company. People have supported you and been loyal customers to you because of that and a lot of that trust has gone into your brand. Now that you are 'on top' you suddenly decide to do an 180 degree turn and go closed source, taking advantage of your now strong brand and even patenting (!?) some of the technology coming out of the community. Personally I believe it is a bad business decision as well since you just removed the extra value that made your $3 d$ printer superior from all the other 'RepRap mods' out there. Now you just told your supporters and customers that they are not important anyway since you are going to make millions selling to all the people who do not care. Well, good luck with that. [Marten, September 26, 2012 at 11:17 pm; comment on: http://www.makerbot.com/blog/2012/09/24/lets-try-that-again/]

I did my own contribution to the debate [September 22, 2012 at 7:02 pm, on: http://www.makerbot.com/blog/2012/09/20/fixing-misinformation-with-information/]. The argument I offered being that MakerBot's goal might not have been becoming a business in the conventional sense of the word, but rather something like Arduino or Ubuntu or the WWW itself. It seems that it didn't impress anybody.

It might be remarked that as many commentators wrote, MakerBot was indeed based and part of a larger socialtechnical-and-desiring machine which I may call the RepRap machine, a fork, or graft, in a way of the Arduino machine. The relation of their respective communities to these machines could be well thought of as a relation of peopling. Indeed both have their initiators, Bowyer and his team, for RepRap, and Banzi, Cuartielles and ali for Arduino, but the rhizomatic way in which they grew or, rather became, could exemplify the concept-idea proposed by Deleuze and Guattari. A widely acknowledged cartography by Emmanuel Giloz, - member of Fab Lab NYBC (Nancy, France), and developer of another RepRap project, FoldaRap [Giloz, 2013] -, even if it might stress a genealogical view of its becoming, - through the possibilities it offers the viewer of imagining the multiple communities of designers, tinkerers, programmers and users behind each variation, it gives an excellent perception of the virus like mutant-proliferant-rhizomatic character of the RepRap machine [Giloz, 2013b]. (Fig. 1) 


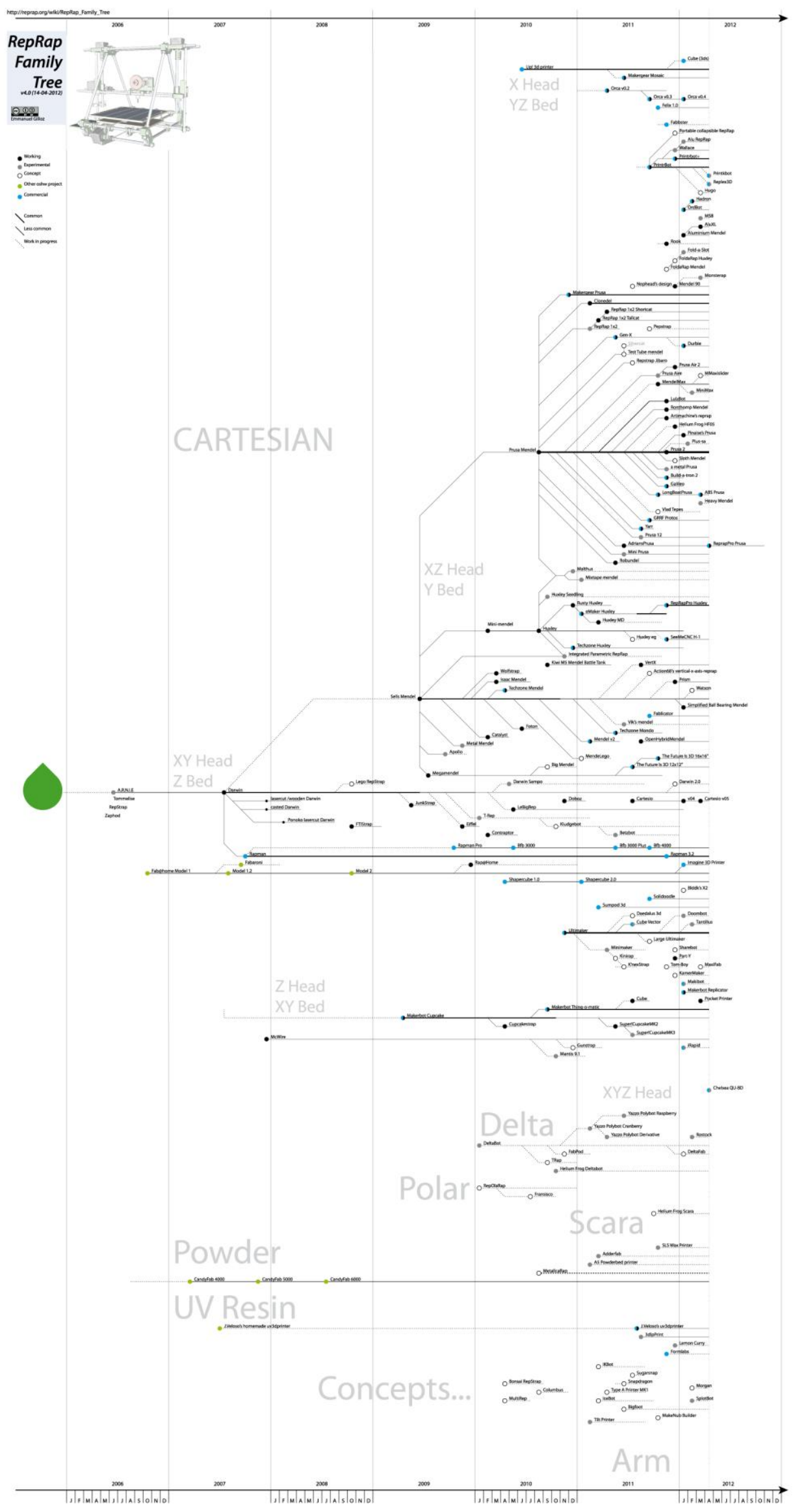


Fig. 1 E. Giloz, 2013, RepRap Family Tree; http://reprap.org/wiki/RepRap Family Tree

The two most outstanding contributions to the MakerBot debates 2012, at least from my point of view, where those by Zach Hoeken, - a disappointed, if not straightforward angry, original founder -, and the fascinating one made by Adrian Bowyer, mixing a certain cynicism with what I would consider philosophical arguments. Follows a selection of both contributions with some comments.

Hoeken did not participate in the MakerBot blog debates, but rather made a brief but tough statement in his own [Hoeken, 2012 (sep 21 2012)].

I do not support any move that restricts the open nature of the MakerBot hardware, electronics, software, firmware, or other open projects. MakerBot was built on a foundation of open hardware projects such as RepRap and Arduino, as well as using many open software projects for development of our own software. I remain a staunch supporter of the open source movement, and I believe the ideals and goals of OSHW remain true. I have never wavered from this stance, and I hope that I never do [...]

[...] it would be a sad day indeed for the open hardware movement. Not only would it be a loss of a large Open Hardware manufacturer, but it would also be a loss of a poster child for the movement. Many people have pointed at MakerBot and said "Yes, OSHW is viable as a business model, look at how successful MakerBot is." If they close those doors, then it would give people who would say OSHW is not sustainable ammunition for their arguments. It would also discourage new OSHW companies from forming. That is a sad thing indeed.

For me, personally, I look at a move to closed source as the ultimate betrayal [...]

And to finish he quoted the latest definition of free hardware [at the time] as proposed at freedomdesigned.org [2013], that had been earlier on endorsed by MakerBot:

Open source hardware is hardware whose design is made publicly available so that anyone can study, modify, distribute, make, and sell the design or hardware based on that design. The hardware's source, the design from which it is made, is available in the preferred format for making modifications to it. Ideally, open source hardware uses readily-available components and materials, standard processes, open infrastructure, unrestricted content, and open-source design tools to maximize the ability of individuals to make and use hardware. Open source hardware gives people the freedom to control their technology while sharing knowledge and encouraging commerce through the open exchange of designs.

Adrian Bowyer, [September 21, 2012 at 10:19 am, comment at: http://www.makerbot.com/blog/2012/09/20/fixingmisinformation-with-information/] even though suscribing Hoeken's opinions in a comment in his blog, composed a subtler response, putting the affair in a wider conceptual context. He started mentioning in an ironic way his support of Open Source:

I shall start with a completely irrelevant fact: I think that Open Source is a good thing. If I ruled the world (which, fortunately for the world and - more importantly - fortunately for me, I don't), all engineering projects from the writing of bank software to the construction of nuclear power stations would be run in an Open Source way.

However, he stated, this was not the reason at all why he decided to license the RepRap project with an Open Source concept; - according to him there was not relation at all! The reason was rather in the realm of life and biology:

RepRap is Open Source because Darwinian game-theoretic analysis says that Open Source is an evolutionarily-stable strategy for a useful replicating machine that is intended to maximize its numbers in the world. This is a completely amoral fact, and it is the reason that I made RepRap Open Source. RepRap is Open Source because that strategy must out-compete closed-source systems in reproductive fitness.

Some of you may think that I am rather lax in my pursuit of those people who would appropriate RepRap technology and close it off, thereby breaking the terms of the GPL. The reason that I am lax (and I am) is because I don't care about those people. I don't care about them because I know that by closing off the path that they have chosen, they have turned it into a reproductive cul de sac; they have made their machine sterile [...] Chasing license infringers will make almost no difference.

If you are taking part in the RepRap project, then I hope that you believe Open Source to be a morally and politically good thing, as I do. But if you don't believe that, you are still welcome to take part, by me at 
least. When it comes to the success or failure of RepRap, moral beliefs, legal constraints and the flow of money are almost completely irrelevant.

It is the evolutionary game theory that matters.

So much by now about the MakerBot 2012 debates - or controversy [Latour, 2007]. We should come back to it in the next future to see what will actually happen and then, maybe, be able to make conclusions. Right now what we might do is to decide whether we buy for our labs the next MakerBot, a Chinese clone or stick to the RepRap evolutionary rhizome. For some reason that I don't fully grasp the Fab Lab Network, - that is, Neil Gershenfeld and closest collaborators -, decided in 2012-13 to switch their earlier official-inventory 3D printer, a Chinese machine, for the MakerBot's closed source Replicator 2. And this fact, offers us a cue to move into the next story.

\section{Peopling the Fab Lab machine.}

It can be said that Fab Labs and the Fab Lab Network constitute one of the social machines incorporating the emerging technologies of digital fabrication. This means, on one hand, that there are several other machines that have digital fabrication as their components.

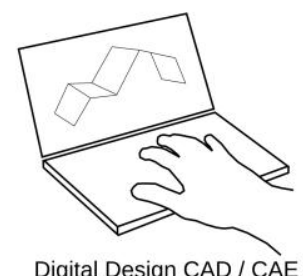

Digital Design CAD / CAE

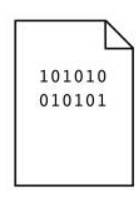

CAM Files

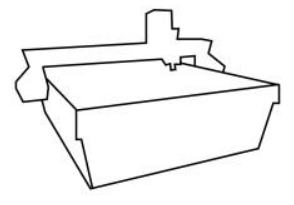

CAM CC Fabrication

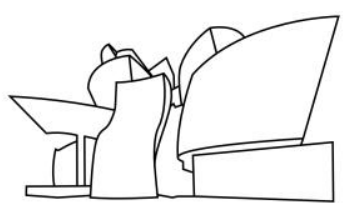

Digitally fabricated building

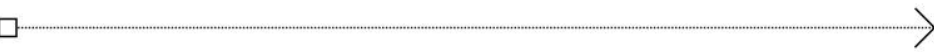

\section{Computers}

Increasingly accessible and personal

CAD / CAE

Computer Assisted Design \& Engineering

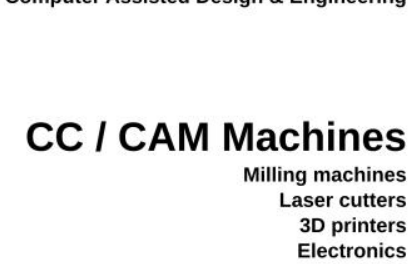

\section{Digital Fabrication}

A new kind of objects Created in "screens" Digitally fabricated With a double digital \& physical condition

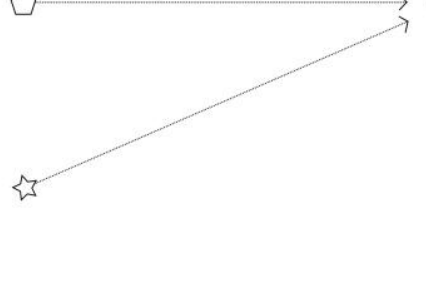

Fig. 2 Image.02: J. Pérez de Lama, 2013, digital fabrication machines diagram

On another hand, it means that Fab Labs are actually a singular composition of technical, social and probably desiring elements. A machine that is made by a field, that could be the web plus the open source communities, that engineers, that distributes on its surface, technical machines and men [and women]; men and woman that people the machine - if we are to follow our conceptual hypothesis.

The actual official definition of what a Fab Lab is has been evolving since the - somehow accidental - foundation of the network. The definition right now is briefly introduced in the so called Fab Charter - more on it later [http://fab.cba.mit.edu/about/charter/]. It says like this: "Fab labs are a global network of local labs, enabling invention by providing access to tools for digital fabrication." As this definition is quite succinct, the new Fab 
Foundation ${ }^{5}$ web site, presented at Fab9 Yokohama, august $2013^{6}$, extends it with further - and some of them new - details. In this most recent version the connection to MIT's Center for Bits and Atoms is especially stressed: "Fab Lab is the educational outreach component of MIT's Center for Bits and Atoms (CBA), an extension of its research into digital fabrication and computation." In this new description of the network, issues such as learning, innovation, support of entrepreneurship, and global networking are highlighted. In a certain way the Fab Lab Network is now under a process of reconceptualization as a lab distributed all over the planet, with a research and strategic center located at MIT.

Continuing with the description in the Fab Foundation site, four things enable a space-group to qualify as a Fab Lab node. First o all, a Fab Lab has to be open to the public "for free or in-kind service/barter at least part of the time each week". Fab Labs are about expanding access to technology. This issue is interpreted in various ways by the different nodes, the formula of a free day or afternoon every week being one of the most common within the network. However, some of the most prominent labs are known to be in expensive and not so accessible institutions, that invent alternative ways to make themselves "open".

The second common trait is that all Fab Labs have to subscribe the already mentioned Fab Charter, a document describing the shared principles of the network. This again was slightly rewritten after Fab8, 2012, to accommodate new visions as well as the increasing demand to join the network by labs all over the world. Right now [Fab Central, 2013] it reads like this - the first point of the charter already commented upon:

\section{What is a fab lab?}

Fab labs are a global network of local labs, enabling invention by providing access to tools for digital fabrication

\section{What's in a fab lab?}

Fab labs share an evolving inventory of core capabilities to make (almost) anything, allowing people and projects to be shared

\section{What does the fab lab network provide?}

Operational, educational, technical, financial, and logistical assistance beyond what's available within one lab

\section{Who can use a fab lab?}

Fab labs are available as a community resource, offering open access for individuals as well as scheduled access for programs

\section{What are your responsibilities?}

safety: not hurting people or machines

operations: assisting with cleaning, maintaining, and improving the lab

knowledge: contributing to documentation and instruction

\section{Who owns fab lab inventions?}

Designs and processes developed in fab labs can be protected and sold however an inventor chooses, but should remain available for individuals to use and learn from

\section{How can businesses use a fab lab?}

Commercial activities can be prototyped and incubated in a fab lab, but they must not conflict with other uses, they should grow beyond rather than within the lab, and they are expected to benefit the inventors, labs, and networks that contribute to their success

\footnotetext{
${ }^{5}$ The Fab Foundation is a US based branch of the Fab Lab network in charge of financial, policy and general organizational issues. Information about it can be found in its web site: http://www.fabfoundation.org, launched in august 2013.

${ }^{6} \mathrm{FabX}$, is the annual conference celebrated by the Fab Lab network. Fab9 took place august 2013 in Yokohama Japan [http://www.fab9jp.com/]. Relevant contents in each FabX are the presentation of the activities developed by the network during the previous year, and the discussion of the route map for the upcoming season.
} 
Even if the changes to the former version [Fab Central, 2007] are subtle, and that it still is published as a "draft", thorough readers might appreciate a small shift away from what could be called a hacker-spirit into a more formal and, may be, business oriented attitude. The most significant changes being the elimination of the points entitled "Access" and "Education". Access stated that "you can use the fab lab to make (almost) anything (that doesn't hurt anyone); you must learn to do it yourself; and you must share use of the lab with other uses and users", while Education read that "training in the fab lab is based on doing projects and learning from peers". The former contents of these points have been integrated, with less emphasis, in other entries.

The third feature of Fab Labs is that all nodes "have to share a common set of tools and processes" [...] "The idea is that all the labs can share knowledge, designs, and collaborate across international borders." If someone makes something in Boston and sends the files and documentation, you should be able to reproduce it somewhere else. If a fabber walks "into a Fab Lab in Russia, he/she should be able to do the same things that he/she can do in Nairobi, Cape Town, Dehli, Amsterdam or Boston Fab Labs. [...] essentially it's the processes and the codes and the capabilities that are important."

The critical machines, - laser and vinyl cutters, CNC precision milling machine and larger scale router, as well as electronic equipment and materials [including micro-controllers to design and fabricate PCBs] - are listed in a constantly updated inventory that is available on-line [Fab Central, 2013]. A new project discussed at Fab9 is to develop regional version of this inventory that optimize supply chains and transportation costs - as the inventory is now strongly based upon US suppliers. The shared open source and free software, tool chains and processes are described in the Fab Academy somehow rhizomatic documentation, as well, available on-line [Fab Central, 2013b].

Again, at Fab9, discussing one of the most interesting Fab Lab projects, the so called "10K lab" - a grass-root lab that would include the minimum equipment at a cost of 10.000 US dollars, - however being still a functional one, and one able to grow with ease into a standard [100K] Fab Lab -, Neil Gershenfeld made an interesting statement concerning standards, - as this common tools and procedures is what they actually aim to be: "A bad standard in the right moment is what makes change happen". Being the point of this statement to stress the need for a standard in order for the network to evolve and advance, even if singularities or upcoming innovations may render it less than optimal for particular, actual or future, situations.

The final feature to qualify as an [MIT] Fab Lab is to partake actively in the global network. This means joining at some moment the afore mentioned Fab Academy, - a global distributed learning course directed by Neil Gershenfeld, including an introduction, theoretical-and-practical, to most of the techniques and procedures shared in the network -, attending the annual network meetings [FabX conferences] and generating and participating in collective projects. A global videoconferencing system set up by the MIT-CBA is one of the main means of communication among labs.

Let's discuss now some considerations on, and problematizations of, the state of development of the Fab Lab Network as it is right now. First of all, there has been a geometric multiplication of the nuber of labs associated to the network in the last two years. Gershenfeld talks about a version of Moore's Law [on the capacity of microcontrollers], which says that the number of labs doubles every year... In fact, the conditions to become an official Fab Lab seem to have loosened compared to how it used to be two-three years ago. The goal apparently being to multiply as much as possible the number of labs worldwide, while before, at least in some regions as for example Spain, it used to be closer to the development of some kind of branding strategy that guaranteed a close affiliation to the core of the network. Growth, of course, means new problems related to standardization, communication and actual sharing of tools, processes and goals. A certain diversification has taken place and various authors are identifying different kinds of labs within the network, - academic and education, community and business oriented ones [Eychenne \& Neves, 2013]. An interesting differentiation has also been made between grass-roots fab labs and institutional top-down ones [The International Fab Lab Association, 2012]. Different and sometimes diverging desiring-machines can be thought to be associated to this diverse approaches. This can be thought of as a problem, a source of conflict in the network evolution in coming years, or as a rich situation, and a certain condition of resistance to over-codification. Of course, labs with longer time of existence, greater funding capacity and initiative, play a stronger role in the evolution of the network (vg Fab Central, - of course -, but also, Fab Lab Barcelona, Fab Lab AS220-Providence, Incite-Focus Fab Lab Detroit, Fab Lab Amsterdam or Fab Lab Norway, among others). However, there is now a move in the network towards regional association that might modify these dynamics. There are also countries like France with a growing Fab Lab movement, and some very successful labs, which up to now seem to willingly keep a certain distance from the network's central developments. There are very relevant labs in the Southern countries, - Africa, South-America, India and South-East Asia... -, however, and without a detailed study, one might wonder whether the majority of them are still rather dependent on traditional North-South cooperation schemes. It needs to be observed in the 
next future whether these labs, already with great differences among them, are able to develop their own original becomings ${ }^{7}$. The geometric growth in the number of global labs together with the loosening of rules to become part of the network certainly introduces an unpredictable character to its development that many consider as something rich, healthy and promising of innovations.

Funding, which is ambiguously spelled in Fab Lab discussions as sustainability, is one of the main questions discussed in meetings. Costs of establishing and running a lab are still significantly limiting of its true popularization. A standard lab is now conceptualized as a $100 \mathrm{~K} \mathrm{lab}$, that is a lab with equipment costing around 100.000 US dollars. But beyond these, running a full fledged lab means leasing or having access to, and maintaining, a space, costs of utilities, and most of all having a small staff, that should include at least 3 to 4 fulltime well-trained (and passionate) persons, taking care of technical, communications, management and funding issues. Regular maintenance and some materials supplies are also necessary to take into consideration. And all this, of course, means an annual budget in the order of magnitude of the initial investment, a circumstance that too often is not accurately enough evaluated. Generating this amount of income is not an easy task for projects that have a strong experimental character and aspire to make its use economy-wise accessible to everyone. Therefore, and until now, labs have developed mixed sources of generating income, often including public funds, when labs are associated to educational, cultural, community development or innovation institutions, or have been created through international cooperation programs. Other sources of income are related to the direct sale of products, and especially services, organization of workshops and educational programs, memberships, materials supply to users, participation and / or collaboration in research and innovation programs, and so on. Financing a lab, with some public funding at least at the beginning, is becoming viable, but it does need strong and knowledgeable dedication in this field by its management team, - another fact that has to be seriously considered in order to achieve successful operation. On the other hand, in countries with a tradition of public education and services, a Fab Lab or rather a Fab Lab network, might be considered a necessary facility associated to schools and technical higher education centers, as much as it is now a library or other kinds of labs; in this cases the question of financing should be considered within the overall perspective, policies and competitive quality of the services supplied by public institutions, and not as an autonomous element with an autonomous balance-sheet. This could also be extended to Fab Labs as community facilities.

The Fab Foundation, renovated in 2013 , is the tool of MIT-CBA to manage network funding and policy lobbying. Until now it had a low profile, but it was announced at Fab9 (2013) a donation of 10 million US dollars, by Chevron, to pursue its goals; - those of the Fab Lab network. Some network members have privately expressed their concern with CBA's and Fab Foundation's funding sources: the US military complex through DARPA at some moment, - DARPA of course is credited with having funded the initial phases of the Internet [Hafner, 2006]-, and now a multinational gas company, with all the environmental and political implications this may mean. It is to be seen the relevance of this partnerships for the Fab Lab network future.

A third, - and last issue to be commented upon on this occasion -, is that of the future technological evolution of Fab Labs. Gershenfeld's route map unfolds in four phases, that are named Fab1.0 to Fab4.0, - to be developed in a 40 to 50 years time line [Gershenfeld, 2013]. Providing technical support to these phases is the actual research work of the Fab Lab section of CBA. As might be known, Fab1.0 was the initial phase, consisting in the establishment of spaces and knowledge using off-the-shelf digital fabrication machines allowing "to make almost anything". Fab2.0, denotes a phase in which a Fab Lab will be able to reproduce itself to make another Fab Lab; that is, it is concerned not with the production of objects, but with the production of machines-that-make-machines [MTM in CBA's slang]. As we have seen before, this is a common goal with the RepRap project; a concept which was actually first enunciated by John Von Neumann in the 1950s [Gershenfeld, 2005, pp: 236-237]. The difference between the RepRap and Fab Lab projects being that the Fab Labs aim to reproduce a whole set of machines, including in a way, the social and procedural components of it. In various instances, Gershenfeld, has compared the early PDP minicomputers, which occupied a full room and were composed by different elements, to the way Fab Labs nowadays are. According to his view, in the coming years fabricators will evolve into integrated machines, as some early experimental prototypes, such as PopFab, developed by Nadya Peek and llan Moyer at CBA [Moyer, Peek, 2012], are already showing. The diagnostics at Fab9 is that the network is at Fab1.5 stage: most of the machines that make up a standard Fab Lab can already be made without great difficulties; however

\footnotetext{
${ }^{7}$ Even if it is difficult to assess the actual work developed in the different labs, judging from the few publications and from the yearly presentations at FabX, it may be said that Fab Labs in the "southern countries" are already developing some of the most interesting projects in the Fab Lab Network, first of all the one in Vigyan Ashram (India), but also those in Nairobi and Aro (Kenya), Yogyakarta (Indonesia), or the several labs in Lima (Peru), among others.
} 
their quality is still lacking behind industrially produced equivalents; and some of the machines like laser cutters are still complicated to fabricate in a DIY-DIWO context [Nortd Lab, 2013].

While the transition to Fab1.0 to Fab2.0 is easily assimilated by the Fab Lab community, Fab3.0 and Fab4.0 will signify a qualitative jump that, yet, is difficult to imagine, and therefore get ready for. Fab3.0 means the production of materials containing within themselves the code of the form and functions they will become and perform. The model of Fab3.0 is the Lego construction system, characterized by functional pieces, metrology, error correction and re-usability [Gershenfeld, 2013]. As I see it, it will mean a jump for fab lab work from a carpentry-supportedby-computational-tools centered kind of work, as it was in Fab1.0, to a software programming kind of work, much closer to working with electronics and micro-controllers. At least for those persons directly involved in the technical parts of these hypothetical fabrication processes. This might be one of the relevant reasons for the Fab Academy's insistence in this kind of electronics design and programming work, which is rather hard for those fabbers that have been attracted to the field because of their design and construction interests. Fab4.0, eventually, will deal with programming materials themselves, much as it happens with "the primeval digital fabrication machine which is made by RNA and DNA" [Gershenfeld, 2005, pp: 238-240]. The fear about this planned evolution is that it will mean a change in what Deleuze and Guattari would call machinic phylum [Deleuze, Guattari, 1987$]^{8}$, jumping into a completely different field that might make for completely different relations between humans and tools - one may wonder if the very strong implication of materiality and bodies that exists in Fab1.0 and Fab2.0, that made many people reconcile themselves with the digital after the early virtual periods, will get lost in these new approaches to fabrication. But of course this will have to be experimented and it will eventually depend on the forms this techniques get to be implemented - and this might be one of the important roles for the network to perform. Gershenfeld, once again [2005, p: 242], proposes a hugely suggestive image, which is that designers or fabbers will have to learn to design with Avogadro-number quantities; - and one may add that they could do it in way homologous to the way they do work now with electrons, when using such bodily intuitive tools as, for example, Arduino has become.

\section{What is to be done?}

Depending on each one's expectations and previous experiences, digital fabrication in its very recent evolution can be perceived as the initial step towards a social revolution, highly promising and exciting, or rather as the latest mirage-of-a-better-society-to-be-achieved-through-technological-change; - the latter alternative with a strong sense of deja vu.

Digital fabrication will certainly function to generate a new series of business and even digital moguls, as Chris Anderson already shows its starting to happen in his book Makers. The New Industrial Revolution [2012]. And hopefully, it will generate an ample community and a, somehow marginal, economy comparable to that of the free and open source software communities and the emerging open source hardware communities, - which in a way have been tolerated until now by the hegemonic powers as long as they can extract value out of them; - as is the case of open source; or as long as they stay really marginal as in the radical free software initiatives ${ }^{9}$. For many, among which I include myself, achieving a statu quo for open source and community oriented digital fabrication similar to that of Free and Open Source software would be already a huge achievement. This, of course is not a given, but it will need lots work, studying, sharing and organizing. It can be considered that relevant parts of the Fab Lab network and all the proliferating hacker and maker spaces, and so on, are moving towards this direction.

Beyond this, a real social revolution connected to digital fabrication seems to me right now very much in the realm of virtuality... of the less probable as Deleuze and Guattari liked to say in relation to their desiring-machines... The popularization of digital fabrication will probably affect the way certain kinds of things are produced, as former revolutions have changed how news, videos or pictures are now made... It might favor some sort of long tail [Anderson, 2012] effect applied to manufacturing... It will indeed lower the barrier to the development of new

${ }^{8}$ Machinic phylum or technological lineage is a, not always clear, concept used by Deleuze and Guattari, for example in 1987, A Thousand Plateaus, pp: 406. Guattari, uses it again in Chaosmosis, 1992, to define his concept of ecosophic object. Here I use it in straightforward way as technological lineage (considering phylum as in phylogenesis) that has associated to it a certain way in which technical machines and humans get assembled, and provides certain conditions in the realm of the production of subjectivity.

${ }^{9}$ Data on the economic relevance of Free and Open Source software are difficult to obtain. FLOSS and related practices maybe marginal from a socio-political point of view, but it is not definitely marginal from an economic point of view, and even less marginal from a production point of view. Some authors argue indeed that its position is actually central to contemporary forms of production [Benkler, 2006; Barnes, 2006; Hardt and Negri, 2009]. 
products... However, the really big promise, the promise that production, through universal access to machines and fabrication processes, will radically reduce or even eliminate its dependence on capital, seems right now a bit far fetched... Like a naive dream... Anyone can make a web site or have a server at home, and contribute to the wealth of the network, but you don't, - maybe with some exceptions, of course -, make your living with it... More and more people can make now their own 3D printers or milling machines, but it is not obvious how they will be able to make their living doing this... It is indeed a technical revolution, but a true social revolution has ultimately to do with rent distribution, and this still is a completely different story...

Guattari, however, never lost his trust in the virtualities of machinic innovation, of technological change, art and social action. And we should not think ourselves beaten before the end of the game. We do have to people the machine. I will suggest here some ideas in this direction. The risks of course, are that our efforts will eventually be captured, that we will fail; that our hearts might end up broken, one more time.

I propose, eventually, three tactics / strategies, that are the following:

[1] The TAZ tactics. Recover the 80's TAZ [Temporary Autonomous Zones] concept [Bey, 1991]; pursuing pleasure and joy, and direct usefulness, developed through autonomous clearly defined projects, that should nevertheless be thoroughly documented and incorporated to a globally shared repository of procedures, practices and projects. Instead of pursuing long term strategies and trying to continuously evaluate against them, perform projects that are clearly limited in scope and time and have the potential to constitute satisfactory achievements in themselves for individuals and community. These will prevent the bitter disappointments that are too predictable when one puts all his/her forces into mid and long term utopian goals.

[2] The minor becoming strategy. Try to work within the existing Fab Lab Network, pushing it in the direction of building a free open-source ecosystem that, even if marginal or minor relatively to the corporate-capitalist development, will attempt to create certain spaces of autonomy for a minority of hackers and tinkerers and even advanced users; pursuing a minor or minority becoming, as Deleuze and Guattari could describe it [Deleuze and Guattari, 1986]. That is, recognize that once more the mutant capitalist desiring-machine will impose itself, but point towards keeping parallel if marginal areas of nomadic knowledge and action.

I would suggest to address this line of work through multiple sub-strategies including at least (1) mastering of some area of expertise by each individual and group; (2) building of transversal and global alliances with activist related fields and people such as open-source software-hardware, mechanical, materials and energy engineering, free culture activism, informal and formal education, alternative-commons economy movements, radical ecologist, right to the city groups, and so on; (3) developing and intense ethico-aesthetic production, a production of imaginary, that can compete with capitalism's all-powerful dominant desiring-machine and it's laminating discourse of success through wealth and "sustainability". I would remind here of the work of Anthony Dunne and Fiona Raby [1991], as well as my own work with hackitectura.net [Perez de Lama, 2006; Moreno, 2011] as some interesting examples in this direction, though developed in different but related fields. Jens Dyvik's work in the field of Fab Labs and digital fabrication is also a relevant reference [Dyvik, 2013].

[3] The post-capitalist strategy. Keep, simultaneously, thinking and working towards grand socio-technical and political schemes that go across multiple fields, and that would contribute to build a future non-post-capitalist world... In some ways, the former strategies-tactics should achieve partial proofs of concept, and windows onto other possible worlds that, only if they become more useful and desirable to the many, might sometime...

To conclude, let's quote one final time Deleuze, now in one of his latest texts, Postscript on the Societies of Control [1992]:

There is no need to ask which is the toughest regime, for it's within each of them that liberating and enslaving forces confront one another. For example, in the crisis of the hospital as environment of enclosure, neighborhood clinics, hospices, and day care could at first express new freedom, but they could participate as well in mechanisms of control that are equal to the harshest of confinements. There is no need to fear or hope, but only to look for new weapons.

\section{Bibliografía.}

ANDERSON, Chris. Makers. The New Industrial Revolution. Londres, Nueva York: Random House Business Books, 2012.

BANZI, Massimo. Getting Started with Arduino. Sebastobol [California]: O'Reilly, 2009.

BARNES, Peter. Capitalism 3.0. A Guide to Reclaiming the Commons. San Francisco: Berrett-Kohler Publishers, 2006. 
BENKLER, Yochai. The Wealth of Networks. How Social Production Transforms Markets and Freedoms. New Haven \& Nueva York: Yale University Press, 2006.

BERARDI, Franco (Bifo). Generación Post-Alfa. Patologías e imaginarios en el semiocapitalismo. Buenos Aires: Tinta Limón, 2007.

BERARDI, Franco (Bifo). La fábrica de la infelicidad. Nuevas formas de trabajo y movimiento global. Madrid:Traficantes de Sueños, 2003

BERNERS-LEE, Tim. Weaving the Web. The Original Design and Ultimate Destiny of the World Wide Web. Nueva York: Harper Business, 2000.

BEY, Hakim. T.A.Z.: The Temporary Autonomous Zone, Ontological Anarchy, Poetic Terrorism. New York: Autonomedia, 1991.

CASTELLS, Manuel. La era de la información. Economía, sociedad y cultura. Volumen 1: La sociedad red. Madrid: Alianza Editorial, 1997 [first English edition: 1996].

DELEUZE, Gilles. "Postscript on the Societies of Control", October núm 59 (Winter 1992), pp. 3-7 1992 [original edition in French 1990].

DELEUZE, Gilles. Foucault. Barcelona: Paidós Studio, 1987 [original edition in French: 1986].

DELEUZE, Gilles, GUATTARI Félix (translation by Brian Massumi). A thousand plateaus. Capitalism and schizophrenia. Minneapolis: University of Minnesota Press, 1987 [original edition in French: 1980],

DELEUZE, Gilles, GUATTARI Félix. Kafka. Toward a Minor Literature. Minneapolis, London: University of Minnesota Press, 1986 [original edition in French 1975].

DELEUZE, Gilles and GUATTARI, Félix (translated by Robert Hurley). "Balance-Sheet of Desiring-Machines, Appendix to 2nd edition of Anti_Oedipe". En: Félix Guattari, 2009, Chaosophy. Texts and Interviews 1972-1977, Semiotext(e). Los Angeles, Paris: Minuit, 1972.

DUNNE, Anthony, RABY Fiona. Design Noir: The Secret Life of Electronic Objects. Zurich: August / Birkhäuser, 2001.

DYVIK, Jens. Making, Living, Sharing [video documentary]; presented at Fab 9 International Fab Labs Conference, Yokohama, Japan [26.08.2013] 2013

ENGELS, Friedrich. The Conditions of the Working Class in England. Londres: Penguin, 2009 [first edition in German: 1845].

EYCHENNE, Fabien, NEVES, Heloisa. Fab Lab. A vanguarda da nova reolucao industrial. Sao Paulo: Fab Lab Brasil, 2013.

FAB CENTRAL, 2013b, Fab Academy, in: http://academy.cba.mit.edu/ [visited 12.09.2013]

FAB CENTRAL, 2013, Fab Lab Inventory, in: http://fab.cba.mit.edu/about/fab/inv.html [visited 12.09.2013]

FAB CENTRAL, 2012, Fab Charter draft october 20, 2012, in: http://fab.cba.mit.edu/about/charter/ [visited 12.09.2013]

FAB CENTRAL, 2007, Fab Charter draft august 30, 2007, in: http://http://htca.us.es/blogs/talleresfablab/informacion/fabcharter/ [visited 12.09.2013]

FLAHERT, Jospeh, 2012, Kickstarter MakerBot clone is legal, but perhaps not ethical, in: http://www.wired.co.uk/news/archive/2012-08/24/makerbot-clone [visited 04.09.2013]

FREEDOMDEFINED.org, 2013, OSHW, http://freedomdefined.org/OSHW [visited 10.09.2013]

GERSHENFELD, Neil, 2013, Digital fabrication, at: http://academy.cba.mit.edu/classes/principles_practices/index.html

GERSHENFELD, Neil, 2012, How to Make Almost Anyhting. The Digital Fabrication Revolution, en www.foreignaffairs.com, Council on Foreign Relations, Inc.; accesible en: http://www.iaac.net/archivos/events/pdf/how-to-make-almost-anything-fo.pdf [academic use only]

GERSHENFELD, Neil, 2005, Fab. The Coming Revolution on Your Desktop - From Personal Computers to Personal Fabrication, Basic Books, Nueva York

GIBB, Alicia, 2010, New Media, Art, Design and the Arduino Microcontroller: A Malleable Tool, Master of Science Thesis School of Art and Design Pratt Institute, New York; accesible [12.2011] at: http://aliciagibb.com/wpcontent/uploads/2010/02/New-Media-Art-Design-and-the-Arduino-Microcontroller.pdf

GILOZ, Emmanuel, 2013b, RepRap Family Tree, in: http://reprap.org/wiki/RepRap_Family_Tree [visited 04.09.2013]

GILOZ, Emmanuel, 2013, FoldaRap, at: http://reprap.org/wiki/FoldaRap [visited 15.09.2013]

GIBSON, William, STERLING, Bruce. The Difference Engine. New York: 20th Anniversary Edition, Ballantine Books Random House, 2011[first edition: 1990]. 
GILOZ, Emmanuel, 2013 [visited 04.09.2013], RepRap Family Tree; in: http://reprap.org/wiki/RepRap_Family_Tree GUATTARI, Félix, Las tres ecologías. Valencia: Pre-Textos, 2000 [original edition, French: 1989].

GUATTAR,I Félix. Chaosmosis. An ethico-aesthetic paradigm. (translation Paul Baines, Julian Pefanis; original French Edition 1992). Bloomingdale-Indianapolis: Indiana University Press, 1995.

HAFNER, Katie, LYON Matthew. When Wizards Stay Up Late. The Origins of the Internet. Nueva York: Simon \& Schuster, 2006 [first edition: 1996].

HARDT, Michael, NEGRI, Antonio. Commonwealth. Cambridge: Belknap Harvard, 2009.

HARVEY, David. Paris, Capital of Modernity. New York: Routledge, 2006 [first edition: 2003].

HOLMES, Brian, 2007. "Future Map, or How the Cyborgs Learned to Stop Fearing and Love Surveillance". in: http://brianholmes.wordpress.com/2007/09/09/future-map/ [visited 12.09.2013]

KELTY, Christopher M. Two Bits. The Cultural Significance of Free Software. Durham and London: Duke University Press, 2008.

LATOUR, Bruno. Reassembling the Social. An Introduction to the Actor-Network Theory. Oxford - Nueva York: Ofxord University Press, 2007 [first edition, English: 2005],

LEVY, Steven. Hackers. Heroes of the Computer Revolution. Sebastopol: O'Reilly, 2010 [original edition: 1984].

LOBOSCO, Katie, 2013, Stratasys buy Makerbot 3D printing company for $\$ 400$ million, in: http://money.cnn.com/2013/06/19/technology/makerbot-stratasys-merger/index.html [visited 10.09.2013]

MORENO, Sergio, PÉREZ DE LAMA, José, ANDRADE, Laura H. [editors]. WikiPlaza. Request For Comments. Barcelona: DPR-Barcelona, 2011.

MOYER, Ilan, PEEK Nadya; 2012. "PopFab the portable fabrication multi-tool” [video], at: https://vimeo.com/45911972 [visited 14.09.2013]

NORTD Lab, 2013, Lasersaur, at: http://labs.nortd.com/lasersaur/ [visited 14.09.2013].

PÉREZ DE LAMA, José, upcoming [written: 2011]. "Emancipatory technologies in computation and architecture. From PCs to personal fabrication". en: Philippe Morel, Christian Girard, Leda Dimitriadis [editores], 2012, Proceedings Computational Politics and Architecture. From Digital Philosophy to the End of Work, ENSAPM and HYX [Orleans, France] disponible en: http://www.hackitectura.net/osfavelados/txts/2012_01_commons_abundance/

PÉREZ DE LAMA, José, 2010. "WikiPlaza and other FLOS [Free Libre Open Source] heterotopias". in: Ewen Chardronnet [editor], Proceedings of Futur en Seine 2009. The Digital Future of the City. Festival for Digital Life and Creativity, Cap Digital, Paris; pp: 229-248

PÉREZ DE LAMA HALCÓN, José. Devenires cíborg. Arquitectura, urbanismo y redes de comunicación. Sevilla: Secretariado de Publicaciones de la Universidad de Sevilla, 2006.

PETTIS, Bre, KAZIUNAS Anna France, SHERGILL Jay. Getting Started with MakerBot. Sebastopol: O'Reilly, 2012

PETTIS, Bre, 2012. "Let's Try that Again". http://www.makerbot.com/blog/2012/09/24/lets-try-that-again/ [visited 08.09.2013]

PETTIS, Bre, 2011b. "All-Star Lineup invests in MakerBot." http://www.makerbot.com/blog/2011/08/23/all-star-lineup-invests-inmakerbot/ [visited 10.09.2013]

PETTIS, Bre, 2011. "Made in my Backyard". pp: 76-83, in: ABEL, Bas van, EVERS, Lucas, KLAASSEN, Roel, TROXLER, Peter [editors]. Open Design Now. Why Design Cannot Remain Exclusive, Amsterdam: Bis Publishers, 2011.

PRUSA, Josef, 2012. “Open Hardware meaning”. In: http://josefprusa.cz/open-hardware-meaning/ [visited 10.09.2013]

RHEINGOLD, Howard. Smart Mobs. The Next Social Revolution. Cambridge: Perseus Publishing, 2002.

RIFKIN, Jeremy, , The Third Industrial Revolution. How Lateral Power is Transforming Energy, The Economy, and The World. New York: Palgrave MacMillan, 2011.

SELLS, Ed, SMITH, Zach, BAILARD, Sebastien, and BOWYER, Adrian, 2007. "RepRap: The Replicating Rapid Prototyper Maximizing Customizability by Breeding the Means of Production". En: Handbook of Research in Mass Customization and Personalization, World Scientific, Proc. Mass Customization and Personalization Conference, MIT, October 2007. Eds: Frank T Piller and Mitchell M Tseng, 2009.

SMITH, Zach aka Hoeken, 2012, "MakerBot vs Open Source - A founder perspective". In: http://www.hoektronics.com/2012/09/21/makerbot-and-open-source-a-founder-perspective/ [visited 10.09.2013].

STALLMAN, Richard. Software libre para una sociedad libre. Madrid: Traficantes de Sueños, 2004 [original English edition: 2002 "Free Software, Free Society"]. 
STERLING, Bruce. Shaping Things. Cambridge: MIT Press, 2005.

The International Fab Lab Association, 2012, report: FABFUSE2012 - first international grassroots Fab Lab conference, in: http://www.fablabinternational.org/es/blog/report-fabfuse2012-first-international-grassroots-fab-lab-conference [visited 12.09.2013]

THINGIVERSE.com, 2012, Thingiverse Terms of Use, in: http://www.thingiverse.com/legal [visited 10.09.2013]

THOMPSON, Chris / Hive76, 2012. "Exclusive: Zach Hoeken on leaving MakerBot and his future". In: http://www.hive76.org/hoeken [visited 10.09.2013]

TORRONE, Philip, 2012 [visited 04.09.2012]. "Sandbox. The \{Unspoken] Rules of Open Source Hardware". In: http://makezine.com/2012/02/14/soapbox-the-unspoken-rules-of-open-source-hardware/

WIGLEY, Mark, 2000. "Man Plus”. en: Fisuras de la cultura contemporánea, núm. 8, ¡Cuesta mucho ser auténtica!, enero 2000, Madrid; pp: 18-44 


\section{Biografía}

José Pérez de Lama Halcón es doctor en Arquitectura y profesor de la Escuela Técnica Superior de Arquitectura de la Universidad de Sevilla. En 2009 fundó el Fab Lab Sevilla en la universidad de la ciudad andaluza, del que continúa siendo director. Durante diez años, junto a Sergio Moreno y Pablo de Soto, participó en el grupo hackitectura.net, llevando a cabo proyectos en los que se relacionaban tecnologías libres, redes sociales y territorios urbanos. Sus trabajos han sido expuestos, entre otros lugares, en el ZKM de Karlsruhe y LABoral de Gijón. Su último libro publicado se titula Yes, We Are Open! Fabricación digital, tecnologías y cultura libres (RUBooks, 2014).

José Pérez de Lama Halcón, PhD in Architecture and professor at the Escuela de Arquitectura, Universidad de Sevilla, where, in 2009 he founded the Fab Lab, which remains a director. For ten years, with Sergio Moreno and Pablo de Soto, he participated in the hackitectura.net group, carrying out projects in which free technologies, social networks and urban territories were related. His works have been exhibited, among other places, at the ZKM Karlsruhe and LABoral of Gijon. His latest book is titled Yes , We Are Open! digital manufacturing , technology and free culture ( RUBooks, 2014 ) . 